\title{
THE PHENOMENON LIVED BY WOMEN IN NURSING CONSULTATION IN THE GYNECOLOGICAL BRACHYTHERAPY
}

\author{
Claudia Regina Gomes de Araújo으. Ann Mary Machado Tinoco Feitosa Rosas², Harlon França de Menezes ${ }^{3}$, \\ Ana Cristina Silva Pinto ${ }^{4}$, Benedita Maria Rêgo Deusdará Rodrigues ${ }^{5}$
}

${ }^{1}$ Ph.D. in Nursing. Nurse, Hospital Universitário Clementino Fraga Filho da Universidade Federal do Rio de Janeiro (UFRJ). Rio de Janeiro, Rio de Janeiro, Brasil. E-mail: clauregingomes@hotmail.com

2 Ph.D. in Nursing. Professor, Departamento de Metodologia da Escola de Enfermagem Anna Nery (EEAN), UFRJ. Rio de Janeiro, Rio de Janeiro, Brasil. E-mail: annmaryrosas@gmail.com

${ }^{3}$ M.Sc. in Nursing in EEAN/UFRJ. Rio de Janeiro, Rio de Janeiro, Brasil. E-mail: harlonmenezes@hotmail.com

${ }^{4}$ Ph.D. in Nursing in EEAN/UFRJ. Professor, Departamento de Enfermagem Médico-Cirúrgico, UFRJ. Rio de Janeiro, Rio de Janeiro, Brasil. E-mail: ana.3105@hotmail.com

${ }^{5}$ Ph.D. in Nursing. Professor, Programa de Pós-Graduação da Faculdade de Enfermagem da Universidade do Estado do Rio de Janeiro. Rio de Janeiro, Rio de Janeiro, Brasil. E-mail: benedeusdara@gmail.com

\begin{abstract}
Objective: to understand the phenomenon lived by women in the nursing consultation in gynecological brachytherapy.

Method: a qualitative study, with an approach using the Sociological Phenomenology of Alfred Schutz. Thirteen women submitted to brachytherapy treatment participated in two radiotherapy services: one located in Rio de Janeiro and the other in São Paulo, Brazil. The data collection took place between February and November 2012, through a semi-structured interview. Results: two concrete categories emerged: Seeking guidance and Experiencing fear. The experience lived by patients is that people who need guidance, fear the illness and treatment caused by the diagnosis and by the performance of procedures.

Conclusion: the nursing consultation for the patient aids the nurse to understand that each patient has a different degree of understanding and that it is effective to personalize this teaching in order to take care of others.

DESCRIPTORS: Nurse's role. Nursing care. Neoplasms of the cervix. Brachytherapy. Qualitative research.

\section{O FENÔMENO VIVIDO POR MULHERES NA CONSULTA DE ENFERMAGEM NA BRAQUITERAPIA GINECOLÓGICA}

\section{RESUMO}

Objetivo: compreender o fenômeno vivido de mulheres na consulta de enfermagem braquiterapia ginecológica.

Método: estudo qualitativo, com abordagem da Fenomenologia Sociológica de Alfred Schutz. Participaram 13 mulheres submetidas ao tratamento por braquiterapia de dois serviços de radioterapia: um localizado no Rio de Janeiro e outro em São Paulo, Brasil. A coleta ocorreu entre fevereiro e novembro de 2012, por meio de entrevista semiestruturada.

Resultados: surgiram duas categorias concretas do vivido: Buscar orientações e Vivenciar o medo. O tipo vivido das clientes é o de pessoas que necessitam de orientação, sentem medo da doença e do tratamento causados pelo diagnóstico e pela realização dos procedimentos.

Conclusão: a consulta de enfermagem para a cliente subsidia o enfermeiro a compreender que cada cliente tem um grau de entendimento e que se faz vigente personalizar este ensinar para cuidar do outro.

DESCRITORES: Papel do profissional de enfermagem. Cuidados de enfermagem. Neoplasias do colo do útero. Braquiterapia. Pesquisa qualitativa. 


\section{FENÔMENO VIVIDO POR MUJERES EN LA CONSULTA DE ENFERMERIA EN BRAQUITERAPIA GINECOLÓGICA}

\section{RESUMEN}

Objetivo: comprender el tipo vivido de mujeres en la consulta de enfermería en braquiterapia ginecológica.

Método: estudio cualitativo, con abordaje de Fenomenología Social de Alfred Schutz. Participaron 13 mujeres sometidas a tratamiento por braquiterapia de dos servicios de radioterapia: uno localizado en Rio de Janeiro y otro en San Paulo, Brasil. La recolección ocurrió entre febrero y noviembre de 2012, por medio de entrevista semi-estructurada.

Resultados: surgieron dos categorías concretas de lo vivido: Buscar orientaciones y Vivenciar el miedo. El tipo vivido de las clientes es el de personas que necesitan de orientación, sienten miedo ante la enfermedad y ante el tratamiento, permeados por el diagnóstico y por la realización de los procedimientos.

Conclusión: la consulta de enfermería para la cliente subsidia al enfermero a comprender que cada cliente tiene un grado de entendimiento y que se hace vigente personalizar este enseñar para cuidar del otro.

DESCRIPTORES: Rol de la enfermera. Atención de enfermería. Neoplasias del cuello uterino. Braquiterapia. Investigación cualitativa.

\section{INTRODUCTION}

By 2030, the World Health Organization (WHO) estimates that 21.4 million cancer cases can be expected as a result of population growth and aging, as well as the reduction of infant mortality and infectious diseases. The National Cancer Institute in Brazil (Instituto Nacional do Câncer - INCA,) warns that with a greater size and significance, cancer has become a worldwide public health problem..$^{1-2}$

Brazilian estimates released by INCA for the year 2017, indicate the occurrence of 600,000 new cases of cancer. Among all types of cancer among women, there are expected to be 205,000 new cases of which 58,000 are breast cancer, followed by 16,000 new cases of cervical cancer. ${ }^{1-2}$

A recent study found that breast cancer mortality is higher in the South and Southeast regions of Brazil, yet there is a great concentration of public health system (Sistema Único de Saúde - SUS) accredited chemotherapy and radiotherapy services.

The forms of cancer treatment may be local (surgery, radiotherapy) or systemic (chemotherapy). Radiation therapy is one of the main therapy modalities for the treatment of neoplasms. It is a localized treatment that uses ionizing radiation produced by devices or emitted by natural radioisotopes, applied directly at the site, at a distance (teletherapy) or next to the tumor (brachytherapy) where the neoplasm was identified. This application is most often performed on an outpatient basis. ${ }^{1-4}$

The high rates of cervical and breast cancer incidence and mortality in Brazil justify the implementation of effective strategies to control these diseases, including actions to promote health, prevention and early detection, treatment and palliative care, when these are required.
Among multi-professional care, nursing is included in the oncological context with the intention of promoting integrative care for health promotion, as well as in the treatment of cancer.

The nursing consultation, a law-supported and private activity of the nurse, is an opportune moment for health actions in the context of oncological care, since it provides direct contact with the patient, allowing individualized and consistent care, becoming a moment for interventions and resolution during the process of illness, but also for the dimensions of the world for women with cancer.

Tending to the brachytherapy theme, it is in the nursing consultation that nurses are given the unique possibility to perform care in the pre, peri and post-application of brachytherapy, such as the preparation for anesthesia, the non-use of medications via the vaginal route, the importance of water consumption, the exercise of vaginal dilation, information regarding pain, bleeding and elimination of vaginal secretion, and always evaluating general health before and after the application.

Gynecological cancers and mammary tumors attack organs that have significant values in Brazilian culture, since it is a disease that violates the intimacy of the women, feelings of doubt, fear and embarrassment can arise, in relation to the therapies proposed for the pathology in question. During care, the proximity established between clients and the nursing team, of teaching and learning could be observed due to the very nature of this care, which happens throughout the patient's treatment process.

This study indicates that the medical literature does not accurately report what it means for the patient to undergo this type of treatment and that the health team does not need the necessary attention in provi- 
ding detailed guidelines regarding the procedure. ${ }^{2}$ Thus, it is understood that the technical information described in the literature is important, however, the emotional state of the clients is also fundmental.

In a recent bibliometric review, there was a predominance of studies that were concerned with contributing to nursing care for the radiotherapy patient, in the prevention, identification as well as the treatment of complications and side effects, as well as in the experiences of the patient and their family faced with the diagnosis and treatment of cancer. ${ }^{6}$

These issues are of concern to nurses during their professional life, therefore they should be encouraged to raise awareness regarding the need for comprehensive care for cancer patients, in order to base their professional practice questions that lead them to the desire to produce new knowledge that contributes to organizational changes and the dissemination of new technologies. ${ }^{6-7}$

In this sense, the objective was to understand the phenomenon lived by women in the nursing consultation in gynecological brachytherapy.

\section{METHOD}

A descriptive, qualitative study guided by phenomenological approach. This approach focuses on the meaning that people give to the facts of life. It is a line of thought based on people's experience of life and what it represents for these experiences, understanding how the phenomenon is experienced. ${ }^{8}$

In this sense, considering that each of us has our own way of seeing the world, it is understood that phenomenology wants to know how the individual incorporates itself in it. It is a philosophical movement that seeks to understand people through the way things are given to them in their life. ${ }^{8}$

The choice of the reference, the Sociological Phenomenology of Alfred Schutz, occurred due to the recognition of the importance of the baggage of knowledge that each client carries within themselves, understanding that every nursing consultation constitutes an opportunity for learning, the fruit of the interpersonal relationships of this encounter.

The interest in the patients was to understand their experiences with the disease and its impact on their lives. They sought to understand what the illness, proposed treatment and the nursing consultation at their disposal meant to them.
Thus, subjectivity and intersubjectivity appeared in the act of sharing experiences, in the exchanges during the nursing consultations. The singularity was evidenced when it was realized that the treatment affects each client of a given form, and this particular world view may be the starting point for the structuring of care.

The study was carried out in two scenarios: the outpatient department of a radiotherapy service of a general public university hospital, located in Rio de Janeiro, and the outpatient department of the Radiotherapy Department of a philanthropic hospital specialized in oncology, located in the State of São Paulo. Both institutions priority service is to clients of the SUS, which receive people for treatment from all Brazilian States.

Thirteen female clients, over 18 years of age, who are lucid and oriented, and who underwent gynecological brachytherapy were participants in the study. The inclusion criteria consisted of patients who wanted to participate in the study, regardless of the staging of the clinical diagnosis or the time of treatment. The general health of the interviewees was not a concern, since only healthy clients are submitted to brachytherapy.

Authorization was requested from the Research Ethics Committees of the hospitals in question, observing Resolution No. 466/2012 of the National Health Council. The study was approved and registered under number 127/11 and number 551/2011, respectively in Rio de Janeiro and São Paulo, and received the CAAE number 0077.0.226.197 -11. After accepting participation, the participants signed the Informed Consent Term (ICT) and, in order to preserve the anonymity of the clients, each one was coded with the letter " $\mathrm{C}$ " and the corresponding number of the interview (C1, C2 through to C13) .

The data were collected through semi-structured interviews, recorded on an audio device, they were performed individually in the radiotherapy service in a reserved place between February and November, 2012. This was followed by a script composed of closed questions regarding the characterization of the participants, such as: age, education, nationality, occupation, profession and time of treatment. For the interviews, the following guiding questions were used: what do you have in mind when you come to the nursing consultation for brachytherapy? How do you experience teaching 
and learning in brachytherapy treatment? Say what it meant for you to teach and learn in the nursing consultation during the brachytherapy treatment.

Careful reading of the speeches of the study participant's speeches was performed, seeking what was common among them for the construction of the categories, which made it possible to comprehensively analyze the intentions of the women in the nursing consultation in the treatment of gynecological brachytherapy.

In the Sociological Phenomenology of Alfred Schutz, the categories are composed of what emerges from the interviewee's speech, whose intentionality of action occurs through the meanings contained therein, showing itself as a typical. ${ }^{8-9}$

\section{RESULTS}

From the speeches of the participants, we obtained expressive meanings, which contributed to the formation of categories. In all, 13 clients were interviewed. The age of clients ranges from 30 to 82 years, with three clients in the 30-year age group.

The treatment time of the disease among the clients interviewed in question was long, a minimum of three months and the maximum of two years. Some clients were away from home since the beginning of therapy, while others make daily trips to the treatment. In addition to suffering from the disease, these clients have to face changes to their routine, given the nature of the duration of cancer treatment.

The following are the concrete categories of experience that emerged from the statements of clients, who received the following denominations: Seeking guidance and Experiencing fear.

\section{Seeking guidance}

The clients seek the nursing consultation to understand their current reality of the cancer diagnosis. The clients' natural attitude is to obtain knowledge about the disease and its treatment, in order for self-care. The conduct of those who have the pathology in question is directed from the diagnosis to the disease itself.

In the statements below, clients express a desire to have information about the treatment itself once the disease has come into their lives. Therefore, their intention is to know more about the illness, to create attitudes referring to the new condition and way of life.
The nursing consultation helped me, it explained a lot to me. I had doubts and I really wanted to ask some questions. I came with doubts, I came with fear, it is great that you give this consultation to guide us, because we come without knowing anything. The doctor explains somethings, but does not give details of the treatment (C1).

It was worth it, for sure. I feel very tired, but I do not give up. And the nursing consultations help people deal with things and better understand the treatment (C2).

In the statements below, in which the nursing consultation reveals itself as a care capable of meeting the expectations of clients, fulfilling its function, which is the search for resolution to the problems that arise. Satisfying the needs of the clients, the nurse adapts the intention of the care to the intention of these in a reciprocity of perspectives.

I think that coming to the consultation with you is good because we do not know how to take care of ourselves. That is to say, when we start the treatment there are many doubts, the doctors do not know if we will be well or not, if this disease will have a cure [...]. It was good for me because I doubted it. I think if I had not come to the consultation with the nursing it would have been worse to face all this (C3).

So! What I had in mind when I came to nursing the first time was the doubts about everything, because I came to do the treatment with no idea at all. I came from another hospital and here they taught me everything, so I have nothing to complain about, it was all excellent (C4).

Well! I went to the nursing appointment and thought it was good. We come with questions in our heads and I thought that the nurse clarified and took away the fear a bit, because we get a little traumatized by all this, right? The consultation made me much calmer [...]. In the case of the consultation with the nurse, she reassured me and my family, because when we come home, everyone wants to know what the treatment was like, what is happening, what I went to do at the hospital that day, if the doctor said something. So, I think the nursing consultation is good because it takes away the doubts, I think we come here for that (C5).

It's simple. The nurse explains, talks about everything, the patient will know how to take care of themselves. Sometimes the patient makes mistakes because she wasn't oriented. I am one of those people who does what I am told. Whatever I have to do for the sake of my health, I do it. So, I think what we have in view, when it comes to the consultation, is really the orientation [...] We need a lot of information to live with this disease. I 
eat well, I work well, I just have a bit of discomfort when I urinate. There are many doubts that we have, one day is not the same as the other (C6).

When I came to the nursing consultation, I came to have guidance, to learn about the treatment. In the other radiotherapy we already know something, but the explanation that is here is in more detail, it is explained better, because the first doubt that we have is how to care for ourselves, if we can eat everything, if we can take medicine, if we have to rest; these things (C7).

\section{Experiencing fear}

This category arose because of the feeling of fear which can be strongly present in the person who is diagnosed with cancer, this varies between the women according to the meaning that the disease has for each one. Represented through the concern which the family has in relation to the disease and death and / or in the imminence of facing the treatment, which most of the time is long and traumatizing. This is due to the characteristics of the available therapies, which are a delayed response, involving surgery, chemotherapy, radiotherapy, bone marrow transplantation and others, being invasive, tiring and painful procedures.

In the next lines, clients related worried about the uncertainty of the future, especially with regard to their children. Concerns regarding the social network was present for them, when they said it is distressing to stay away from home, family and work. Due to them not knowing what lies ahead, it was difficult for them to prioritize and devise a course of action. Their lives are suspended because of the disease.

Faced with this situation, the nurse must teach without pragmatism and learn with tolerance, giving a voice to the clients, similar to the following.

I have three small daughters. My life is like this, Oh [makes a gesture with her hands coiled together]. I had to leave my husband in Belem and I came here with the girls, because I would miss them too much if I went without them. Wow, our heads suffer, this disease isn't easy, no. (C7).

For me, one thing that is difficult is to stay away from home. I have children and grandchildren, my daughter lives with me, or rather, I live with her [...]. It's too difficult to stay away from my grandchildren. There are a lot of them, they make the biggest mess but I miss it (C3).
An important aspect in the nursing consultation is about the educational process that must be based on what the client believes. The following accounts explain the above.

I have to raise my children and I cannot stop my life, God forgive me, not knowing if I'm going to die or not. Sorry, but we have to be honest and use the words. I just wanted to know if I could raise my children (C6).

My neighbor, who was very much my friend, died of this disease and she had too much pain, she complained a lot, she even died in my arms (C8)

The following statements reflect the thinking of those who need to move away from their way of life, when facing cancer.

I had the biggest scare because I've never had any diseases [...]. Then I started to feel pain and went to the health plan doctor. I'm from the interior of São Paulo, they told me to come here, that's when I had clarification. They said the kind of tumor I had. Then I could start to treat it. Look, I'd rather go and come back every day, my city is near here. Despite having to travel every day, here I feel safe [...] (C9).

Now I just want to know if I'm going to be all right. I want to go back to work, so it can't go on like this, I just stopped because I got sick. Luckily the service here is very good. The consultation with the nurse was good, because she talked to me and explained many things, but also asked about me, how I lived, what I work as, and that was very good (C10).

The expectation of termination of treatment is described in the following statements.

I'm still a little nervous; I had the third injection today and I'm crazy to end the treatment soon. I'm just going to settle down when it's all over (C11).

It's bad to leave our house, leave our things. At least the treatment is over today, I can go home (C3).

\section{DISCUSSION}

The person's age influences the way the disease alters his or her life. Sexuality, the fact that the woman is in the reproductive phase, the possibility of mutilation (through hysterectomy, among other surgeries), the person's tolerance to pain, are all factors that must be considered.

Cancer is still linked to the belief that its carrier is doomed to die. This is often due to the lack of knowledge about the disease and its current therapeutic possibilities. 
A study found that beliefs about cervical cancer in urban and rural women are more incidental in urban women because they believe the disease is caused due to bad luck or fate and that there is not much that can be done to prevent cervical cancer. ${ }^{11}$ The diagnosis of cancer directly affectsthe patient's ego, which is extremely fragile and vulnerable. This situation generates anguish because of the fear of pain, separation and death. ${ }^{12}$

The life of those who find themselves with cancer is modified, regardless of how they face this new phase in their life, where they can denote perplexity and fear of finitude, giving rise to concerns about recovery and the quality of survival. It is common for women to go through a period of questioning about how they have been leading their lives up to that time, with a reassessment of beliefs and values. ${ }^{10}$ This type of situation is defined as a system of relevancy when we need to decide which elements should be changed in our lives. ${ }^{8}$

In this case, as a facilitator, it is incumbent upon the nurse in the nursing consultation to meet the educational needs of these clients, so that their full potential for coping with the disease is utilized, once their living habits can be modified.

This circumstance is due to intersubjectivity, which is a situation shared by two or more persons capable of communicating with each other. ${ }^{8}$ If one understands the other's intention and corresponds to it, it fulfills their expectations.

Professional nursing care implies a specific type of social relationship between the subjects who participate in it. It is a care that adds the technical-scientific dimension, which differentiates it from that practiced by common sense, besides being based on the intersubjectivity, the knowledge base and the biographical situation of the caregiver. ${ }^{9}$

A study shows that the relationship between professionals and clients can have important consequences, both in adherence and in therapeutic results, because trust in treatment and in the professional is necessary. Technological advancement and the consequent media disclosure of therapeutic successes, confirmation and therapeutic planning for the client require the sensitivity of health professionals and adequate communication with the use of simple language in order for the client and his / her family to understand the disease, treatment and that they can rely on professional staff. ${ }^{12}$
In the pursuit of care by the clients, the presence of the multidisciplinary team is highlighted, with each professional acting according to his / her competence, joining forces for the service to occur. When we refer patients to other specialties, we are strengthening this type of partnership. Targeting the patient properly within the health system is the duty of all the working teams, so that we can achieve a humanized care. In this process, we as clients and professionalsare all teaching and learning.

In this way, a multiple approach with different defense weapons contributes to the overall progress of cancer knowledge. Educational advocacy involves improving cancer awareness among clients, their families, and the public through different modalities, such as encouraging dissemination through print media, radio, and even social events, they can all be used as platforms where this knowledge can be disseminated. ${ }^{13}$

While still reflecting on partnerships, we identified that in the process of caring the nurse must take into account the relationship of the person cared for by their peers. In the testimonies, the importance of the family was observed and recorded in the context of the patient. It is an example of the educational action being extended to those who live with the client, who for the Sociological Phenomenology can be interpreted as understanding the importance of the social network of the other.

When seeking guidance, patients have special concerns about self-care and, just as the doubts are peculiar to each patient, the nursing orientations should also pay attention to the uniqueness of the subjects. What is wanted is that the nursing care carried out in the consultation helps patients to cope with cancer, making them as independent as their general health condition allows them to be.

Understanding intentionality as acts of work in progress, driven by the objects and objectives that will be done, ${ }^{8}$ the natural attitude of the nurse in caring for the client should be to assign a care that has meaning for this. After all, cancer is a devastating disease, with staggering statistics, often with gloomy prognosis, ${ }^{5}$ therefore, the planning of care for these clients should be carried out with flexibility in order to contemplate their biographical situation. There is a common aspect in the clients' speech: the importance of the educational process, when they mention the search for guidqnce and that this 
search should be done repeatedly throughout the treatment whenever necessary. The client's situation with regard to gynecological brachytherapy creates the natural attitude of trying to face the procedure in the best possible way for them.

The hope of healing becomes a priority in the lives of these people and all their actions are directed towards this goal. This generates a typical pattern of conduct, which is to want to be informed to experience the next phase. Therefore, the need for a behavior change of these clients must be satisfied according to the individualality of each one of them, adapting the proposal of care to these needs, and this occurs when the interests of the client and the nurse become mutual, within the educational process.

This process is related to several practical issues, such as the planning of self-care at home and the organization of the daily life of these clients. In the interviews conducted for the current study, included in the reasons that motivate the clients' attendance to the nursing consultations, we find the fear, doubts in general, anxiety and the genuine need for clarification. If the world of human life is changed with the appearance of any disease, it is up to the nurse to accompany the sick person and their social network in this process of change, to experience the current reality.

Thus, we identified the value that the patient has for guidance and that the educational process should be configured as nursing care within the health units, and not just as an isolated activity, outside the context of care.

In this sense, teaching and learning is not only the reproduction of technical conducts related to scientific procedures. It is teaching and learning to think, to act, to behave appropriately to experience this cycle of life that presents itself in the singularity of each subject, whether patient or nurse. After all, the nursing consultation aims to meet the needs of the human being, with quality of life being the principal objective.

Faced with such perspectives about the intersubjective exchange relationship existing in the nursing consultation, the actions of the consultation must be carried out in an integrated and participative way. In this context, it is necessary that the nurse is perceptive and sensitive while learning about the experiences of women, being aware that each one is unique and reacts, equally, differently. ${ }^{14}$
A study of groups of women with cervical cancer with precursor lesions in reproductive and non-reproductive age showed that the fear was different, but that it did exist for each group. For women of non-reproductive age, the cancer can be understood as a threat, being represented as a serious illness and can lead to death, as a result, feelings of distress and fear may arise. These feelings related to cancer in general and to the cervix-uterine are created and perpetuated by the very discourse of risk and vulnerability. The group of women of childbearing age demonstrated their fear of the possibility of loss due to the strong identification of women with maternity. ${ }^{15}$

The perspective of finitude permeates the minds of patients which is deserving of special attention. Since the perception of death has a special meaning for each human being, the nurse must be vigilant not to share his own values about dying. The professional must perform the care from the perspective of phenomenological reduction, which happens when we leave our beliefs and opinions aside in order to hear what the other is saying, without judgment. ${ }^{8}$ During the process of illness, the biographical situation of the clients is modified several times, depending on the stage in which they are on the cancer treatment, with the possibility to compare their mood before and after it. The person diagnosed with cancer is removed from their life as they know it and placed in another, with whom they have to live and establish new relevance, since the new priority is their health.

According to Social Phenomenology, ${ }^{8}$ in this case it is necessary to consult the stock of current knowledge to make plans for the future, and to resolve, as far as possible, the question that cancer takes precedence over the original project, prior to clinical diagnosis, for those who are sick, although they have to cope with this new imposed relevance, they do not abandon their previous knowledge of the current health condition. The past is not erased. What changes is intentionality, which will be defined from how the individual will face the process of becoming ill.

Close to the end of the treatment the patient's perspective of the future reappears, the patients comment on being relieved by this phase. For them, it is possible to rethink their priorities, renew their intentions and plan their conduct forward. Nursing 
care should also be directed towards the future, reinforcing the importance of self-care to the patient and reminding them what these are, according to the needs of each one. In this final phase, while planning the care for the next patients the nurse can reflect on the learning she/he had with each client. According to the testimonies, the fear of the treatment has several aspects. Fear of the unknown can acquire worrying dimensions and significantly affect the patient's ' emotional state if it is not circumvented or controlled. The sensations can be so distressing that they lead to the abandonment of the treatment or the inefficacy of the same by not attending the health unit as they should or not fulfilling all the steps of treatment. An international study reveals that the situation of social vulnerability for people with cancer increased their suffering, in addition to social inequalities, which are apparently linked to the social hierarchy, which also increased the suffering of people with cancer. ${ }^{16}$

In view of the above, it is important that all doubts are resolved and all questions exhausted in the educational process. There is no recurring question. A subject that was not resolved is an issue that was not explored as it should have been. Being afraid is a natural attitude of those who have cancer. It is a feeling that only diminishes or ceases to exist when everything about it is handled properly.

In this sense, the application of health education strategies, especially those performed by the nurse, must meet the learning needs, where sometimes not all individuals realize their own need to obtain knowledge about a certain subject, and it is up to the nurse to help them identify, clarify and prioritize their needs and interests. ${ }^{17}$ Thus, nurses should be able to perform qualified listening, with principles of humanization, accountability, and commitment to the needs of the other. For this perspective to become real it is necessary for the nurse to turn discourse into actions. ${ }^{18}$

If empathy occurs during contact with the nurse, a relationship based on help can be established between the nurse and the patient, culminating in problem solving. This characterizes the exchange that exists in the teaching and learning of each patient and each nurse during the treatment process. The patient learns and also teaches how to manage fears, and the nurse learns and teaches how to understand the causes of these fears and to create possibilities for overcoming them.
With the Social Phenomenology referential, it is possible to reveal that the clients of care in nursing, both individually and collectively, are inserted in a socio-historical and cultural context that needs to be valued. In this sense, the biographical situation and the knowledge available to them are important indicators for the planning and implementation of professional care actions.

Thus, this referential brings the importance of thinking about care from the perspective of the relationships emanating from it to light, considering the perspective of the subjects involved in nursing caregiving, ${ }^{19}$ looking at the world of social life, resorting to this method of descriptive analysis of the constitution of everyday experience. ${ }^{20}$

Some limitations of the study must be considered, which may hamper its generalization of results, such as the limited number of participants and the possibility of sociocultural variables that may influence the study.

\section{CONCLUSION}

It was verified that for women who go through the nursing consultation before gynecological brachytherapy the confrontation of the therapy is smoother. In fact, this smoothness, on several occasions, contributed to the reduction of anesthesia time, a fact which was observed during daily care. Therefore, nursing consultations reduce anxiety and assist patients in understanding the proposed treatment.

The participants in this study were women undergoing a long period of treatment, which can vary from months to years. Some clients needed to stay in the vicinity of the institutions because they live far away. Fear and worry about the disease modify the daily life of these women. As uncertainty for the future is a constant for the patient undergoing gynecological brachytherapy, it is difficult for her to define a standard attitude towards cancer, due to the condition affecting each woman individually. It is necessary for the nurse to learn how this happens for each patient and to help her with the experience of the illness and the treatment.

Reflecting on the individuality of the patients interviewed in this study, it was gratifying to note that, with the practice of nursing consultation, the nurse becomes a reference for these patients, in partnership with the other members of the hospital team. 
Thus, it is necessary to consider the broad context regarding the offer of nursing consultation in radiotherapy in other services and the impact that women give to the painful and invasive process of brachytherapy, and the institutions which can modify their protocols from the voice of those who experience this.

The present study raises reflections about the meanings of the experience of women with cancer and their reflections in their social relations and the results can be widely appreciated and discussed by the scientific and academic community, including the nursing area. The prospects can be expanded in other health care services, as well as complex care in gynecological cancer. Therefore, we hope to have collaborated in the understanding of these women who experience the treatment from the reality of daily life.

\section{REFERÊNCIAS}

1. Ministério da Saúde (BR). Instituto Nacional do Câncer. Estimativa 2016: Incidência do câncer no Brasil. [Internet] Rio de Janeiro; 2015. Available from: http://www.inca.gov.br/estimativa/2016/

2. Panzetti TMN, Santana ME, Costa MSCR. Research on cancer nursing cervical the period 2008 to 2013. J. Health Biol Sci. 2015; 3 (1):46-51.

3. Azevedo e Silva G, Bustamante-Teixeira MT, Aquino EML, Tomazelli JG, Santos-Silva I. Access to early breast cancer diagnosis in the Brazilian Unified National Health System: an analysis of data from the Health Information System. Cad Saúde Pública [Internet]. 2014 [cited $2015 \mathrm{Jul}$ 25]; 30(7):1537-50. Available from: http://www.scielo.br/pdf/csp/ v30n7/0102-311X-csp-30-7-1537.pdf

4. Leite FMC, Ferreira FM, Cruz MAS, Lima EFA, Caniçali CP. Nursing diagnosis related to the adverse effects of radiotherapy. Rev Min Enferm. 2013; 17(4):946-951.

5. Ministério da Saúde (BR). Secretaria de Atenção à Saúde. Departamento de Atenção Básica. Controle dos cânceres do colo do útero e da mama [Internet]. Departamento de Atenção Básica. Brasília: Ministério da Saúde; 2013 [cited 2013 Jan 5]. Available from: http:/ / bvsms.saude.gov.br/bvs/publicacoes/ controle_cancer_colo_utero_mama.pdf

6. Ferreira SMA, Gozzo TO, Panobianco MS, Santos MA, Almeida AM. Barriers for the inclusion of sexuality in nursing care for women with gynecological and breast cancer: perspective of professionals. Rev. LatinoAm. Enfermagem [Internet]. 2015 [cited 2015 Jul 20]; 23(1):82-9. Available from: http://www.scielo.br/ pdf/rlae/v23n1/pt_0104-1169-rlae-23-01-00082.pdf

7. Rosa LM, Misiak M, Marinho MM, Ilha P, Radünz V, Fermo VC. Radiotherapy and brachytherapy in nursing: a bibliometrical review. Cogitare Enferm [Internet]. 2015 [cited 2015 Jul 23]; 20(2):408-16. Available from: http://ojs.c3sl.ufpr.br/ojs/index. $\mathrm{php} /$ cogitare/article/view/38866

8. Schutz A. Sobre fenomenologia e relações sociais. Petrópolis (RJ): Vozes; 2012.

9. Monteiro ACM, Rodrigues BMRD, Pacheco STA. O enfermeiro e o cuidar da criança com câncer sem possibilidade de cura atual. Esc. Anna Nery [Internet]. 2012 [cited 2015 Sep 01]; 16(4):741-6. Available from: http:/ / www.revistaenfermagem.eean.edu.br/ detalhe_artigo.asp?id=812

10. Vieira EM, Santos DB, Santos MA, Giami A. Experience of sexuality after breast cancer: a qualitative study with women in rehabilitation. Rev. Latino-am. Enfermagem. [Internet]. 2014 [cited 2015 Sep 02]; 22(3):408-14. Available from: http:/ / www.scielo.br/ pdf/rlae/v22n3/pt_0104-1169-rlae-22-03-00408.pdf

11. Marván ML, Ehrenzweig Y, Catillo-López RL. Fatalistic beliefs and cervical cancer screening among Mexican women. Health Care Women Int [Internet]. 2016 [cited 2016 Jun 30]; 37(1):140-54. Available from: doi 10.1080/07399332.2014.959169

12. Barros AG, Melo MCP, Santos VEP. Meanings attributed to cancer by a group of women. Rev Enferm UERJ [Internet]. 2014 [cited 2015 Aug 29]; 22(1):129-33. Available from: http://www.facenf.uerj.br/v22n1/ v22n1a20.pdf

13. Mutebi M, Edge J. Stigma, survivorship and solutions: addressing the challenges of living with breast cancer in low-resource areas. SAMJ, S. Afr Med J. [Internet]. 2014 May [cited 2016 Jun 30]; 104(5):382. Available from: http://www.scielo.org.za/pdf/ samj/v104n5/30.pdf

14. Frohlich M, Benetti ERR, Stumm EMF. Experiences of women with breast cancer and actions to reduce stress. Rev enferm UFPE on line [Internet]. 2014 [cited 2015 Aug 29], 8(3):537-44. Available from: http://www. revista.ufpe.br/revistaenfermagem/index.php/ revista/article/viewFile/5695/pdf_4674

15. Carvalho MCMP, Queiroz ABA, Moura MAV. Social images among women with precursory lesions of cervical cancer: study of social representations. Rev enferm UERJ [Internet]. 2014 [cited 2015 Aug 29]; 22(3):383-8. Available from: http:/ / www.facenf.uerj. $\mathrm{br} / \mathrm{v} 22 \mathrm{n} 3 / \mathrm{v} 22 \mathrm{n} 3 \mathrm{a} 15 . \mathrm{pdf}$

16. Saarnio L, Arman M, Ekstrand P. Power relations in patient's experiences of suffering during treatment for cancer. J Adv Nurs [Internet]. 2012 [cited 2016 Jun 30]; 68(2):271-9. Available from: doi: 10.1111/j.13652648.2011.05731.x 
17. Vasconcelos CTM, Cunha DFF, Coelho CF, Pinheiro $\mathrm{AKB}$, Sawada NO. Fatores relacionados ao não comparecimento à consulta para receber o resultado do exame colpocitológico. Rev. Latino-Am. Enfermagem [Internet]. 2014 [cited 2015 Sep 03]; 22 (3):401-7. Available from: http://www.scielo.br/pdf/rlae/ v22n3/pt_0104-1169-rlae-22-03-00401.pdf

18. Costa PCP, Garcia APRF, Toledo VP. Welcoming and nursing care: a phenomenological study. Texto Contexto Enferm [Internet]. 2016 [cited 2016 Jun 30]; 25(1):e4550015. Available from: http:/ / www.scielo.br/pdf/tce/v25n1/0104-0707tce-25-01-4550015.pdf
19. Jesus MCP, Capalbo C, Merighi MAB, Oliveira DM, Tocantins FR, Rodrigues BMRD, Ciuffo LL. The social phenomenology of Alfred Schütz and its contribution for the nursing. Rev Esc Enferm USP [Internet]. 2013 [cited 2015 Jul 05]; 47(3):736-41. Avaliable from: http://www.scielo.br/pdf/reeusp/v47n3/00806234-reeusp-47-3-00736.pdf

20. Zeferino MT, Carraro TE. Alfred Shütz: from theoretical-philosophical framework to the methodological principals of phenomenological research. Texto Contexto Enferm [Internet]. 2013 [cited 2015 Jun 20]; 22(3):826-34. Avaible from: http:/ / www. scielo.br/pdf/tce/v22n3/v22n3a32.pdf 